\title{
The protective effect of methylene blue in lungs, small bowel and kidney after intestinal ischemia and reperfusion ${ }^{1}$
}

\author{
A influência do azul de metileno na prevenção da lesão pulmonar, intestinal e renal \\ após isquemia-reperfusão intestinal
}

\author{
Fernando Hintz Greca ${ }^{\mathrm{I}}$, Neuza Maria Ferraz de Mello Gonçalves ${ }^{\mathrm{II}}$, Zacarias Alves de Souza Filho ${ }^{\mathrm{III}}$, Lúcia de \\ Noronha $^{\mathrm{IV}}$, Ruy Fernando Kuenzer Caetano da Silva ${ }^{\mathrm{v}}$, Michel Risnic Rubin ${ }^{\mathrm{v}}$ \\ ${ }^{I}$ Professor of Experimental Surgery PUC- PR. \\ II Professor of Biochemistry at PUC-PR. \\ III Professor of Experimental Surgery PUC-PR. \\ IV Professor of Pathology at PUC-PR. \\ $\checkmark$ Medical student (PUCPR).
}

\section{ABSTRACT}

Purpose: To study the role of methylene blue as an inhibitor of superoxide production by xanthine oxidase. Methods: Thirty-two Wistar rats were divided into 2 groups of 16 animals: the control group and the experimental group. All were submitted to a laparotomy for the occlusion of the cranial mesenteric artery during 60 minutes. The reperfusion was confirmed by the pulsation of the artery after the release of the temporary ligature and color change of the intestines. In the animals of the control group, $2 \mathrm{ml}$ of saline were injected in the peritoneal cavity and in the animals of the experimental group, $2 \mathrm{ml}$ of methylene blue were injected in the peritoneal cavity. After reperfusion for 4 hours, the animals were then sacrificed. The lungs were excised from all 32 rats. Simultaneously, the small intestine and kidneys were ressected in 20 animals (10 from the control group and 10 from the experimental group). Samples of the organs were taken to evaluate the action of xanthine-oxidase, for histopathology studies and for characterization of the edema. Results: In the animals of the experimental group, the inflammatory lesion as well as the edema in the lung was greater than in the control group. The intestinal and renal lesions were similar in both groups, but the lung damage was superior to that observed in the intestines and kidneys. . Conclusion: Despite similar action of the xanthine oxidase in the control and the experimental group, after intestinal ischemia and reperfusion, the protective effect of methylene blue was observed only in the lungs of the experimental group.

Key words: Methylene blue. Ischemia-reperfusion injury. Xanthine-oxidase

\section{RESUMO}

Objetivo: Estudar a ação do azul de metileno como supressor da produção de radicais livres de oxigênio, atuando como receptor alternativo de elétrons na enzima xantina-oxidase.Materiais e Métodos: Foram utilizados 32 ratos Wistar (Rattus norvegicus albinus, Rodentia mammalia) divididos em 2 grupos de 16 animais, os quais foram denominados grupos: experimento e controle. Todos os animais foram submetidos a laparotomia mediana e oclusão da artéria mesentérica cranial por 60 minutos. A reperfusão foi confirmada por meio da verificação do reaparecimento da pulsação da arcada mesentérica. Foi então administrado no grupo experimento $2 \mathrm{ml}$ de azul de metileno $1 \%$ intra-peritonealmente, enquanto que no grupo controle o mesmo volume de solução salina isotônica foi administrado pela mesma via. Após 4 horas de reperfusão, os animais foram sacrificados. Os pulmões foram ressecados nos 32 animais do estudo, ao passo que o intestino delgado e os rins em 20 animais (10 ratos do grupo controle e 10 ratos do grupo experimento). Amostras dos órgãos retirados foram obtidas para medição da xantina-oxidase, análise histopatológica e avaliação do edema. Resultados: O dano pulmonar encontrado no grupo controle foi superior ao encontrado no grupo experimento. Observou-se uma maior formação de edema e uma maior atividade inflamatória nos pulmões do grupo controle. O dano intestinal e renal encontrado foi semelhante em ambos os grupos, mas não tão intenso quanto o dano pulmonar. A atividade da xantina-oxidase foi semelhante em ambos os grupos. Conclusão: A atividade protetora do azul de metileno foi evidenciada nos pulmões, todavia o mesmo efeito não foi demonstrado nos rins nem no intestino delgado.

Descritores: Azul de metileno, isquemia-reperfusão, xantina-oxidase

1. Research performed at Department of Experimental Surgery of the Pontifical Catholic University of Paraná (PUC-PR), Brazil. 


\section{Introduction}

Mesenteric ischemia may be caused by impairment of arterial or venous circulation as a result of occlusive disease, like embolism or thrombosis or as a result of non occlusive disease like spastic mesenteric insufficiency or low flow syndrome. The severity of these conditions is not only related to the ischemia itself, but to the eventual tissue reperfusion that can cause more severe lesions in different organs and systems. ${ }^{1,2,3}$

Since the 1990's, many studies have been done regarding systemic inflammatory alterations from ischemic reperfusion lesions (IR). The early identification of this process is fundamental for the attenuation and prevention of local and systemic effects of tissue damage arisen mainly in the reperfusion phase. ${ }^{4}$.

The pathophysiology of the lesion from IR is directly related to the excess generation of free radicals of oxygen both from the parenchymal cells themselves or from the inflammatory cells that usually invade these tissues.

Tissue ischemia and consequently the decrease of oxygen intake by the cells result in a decrease of ATP production and consequently cellular energy, creating an ionic gradient on the cell membrane that alters the redistribution of calcium in the cytosol. The increase in the concentration of cytoplasmatic calcium leads to the activation of a protease that can convert xanthine dehydrogenase into xanthine oxidase $^{5,6}$. Concomitantly to a cellular depletion of ATP, there is an accumulation of AMP which is catabolized into adenosine, inosine, and then hypoxanthine.

During reperfusion, however, the accumulated hypoxanthine is transformed by the xanthine oxidase, in the presence of molecular oxygen, into free radicals of oxygen: superoxides, peroxides, and hydroxys $1^{6,7,8}$, resulting in a systemic inflammatory process characterized by the increase in endothelial permeability to fluids, macromolecules, and inflammatory cells ${ }^{6,9,10}$.The deleterious effects of reperfusion surpass the effects of the actual ischemia, since the metabolic toxins accumulated during the period of ischemia will be distributed throughout other organs $s^{1,11,12,13}$.

In the intestine, IR results in tissue lesion and morphological alterations, compromising the absorptive function ${ }^{14}$. The high intestinal sensitivity to ischemia induces higher concentration of xanthine oxidase in the intestinal villosities. The free radicals and oxidants act directly on the activation of polymorphonuclear neutrophils (PMNs) and on the adhesion to the vascular endothelium, thus altering the permeability of the vascular endothelium and the intraluminal proteic coefficient ${ }^{6,7}$.

Regardless of short or long periods of complete ischemia, renal function can be severely attacked due to the sustained circumstances. The magnitude of renal dysfunction is proportional to the extension of the tissue damaged and its reversibility depends on the duration of anoxia ${ }^{15}$. Microvascular injury, induced by inflammatory leukocytes, particularly PMNs, releases various cytotoxic components: cytokines, complements, free radicals, and adhesion molecules which, in addition to adherence to the vascular endothelium, cause a greater decrease in renal blood flow and consequently compromise the renal tubular function $^{15,16}$.

In the lungs, free radicals of oxygen induce an inflammatory lesion, increasing the expression of adhesive molecules, cytokine production and membrane permeability ${ }^{17}$. The greater membrane permeability to macromolecules and inflammatory cells, the greater is the tissue damage, resulting in a further increase of chemical mediators, free radicals, proteases. This features are responsible for the adult respiratory distress syndrome (ARDS) ${ }^{6}$.

Methylene blue suppresses the production of superoxide radicals by acting as an alternative receptor of xanthine oxide electrons, competing with molecular oxygen for the transference of these electrons. The pair of electrons produced by each enzymatic oxidation is transferred to methylene blue from the iron-sulfuric center of xanthine oxidase, where molecular oxygen is converted into superoxide. Thus, the generation of these radicals is reduced $^{18,13}$.

Methylene blue, as an inhibitor of oxygen free radicals production, reduces the expression of adhesive molecules, the excess of cytokines and competing with nitric oxide through cyclase guanylate ligation, reducing the risks of hypotension and shock ${ }^{13,18,19}$.

The aim of the present study is to evaluate the protective effect of methylene blue against oxygen free radicals formation in the intestinal, renal and pulmonary lesion caused by ischemia and reperfusion.

\section{Methods}

This experimental study was approved by the Ethics Committee on Animal Research of the Pontifical Catholic University of Paraná and followed the orientation of COBEA (Brazilian College of Animal Experimentation).

Thirty-two male Wistar rats (Rattus novegicus albinos, Rodentia mammalia) between 100 and 130 days old and weighing between 250 and 300 grams were used. The animals were randomly divided in two groups of 16 rats. After twelve hours of fasting, they were submitted to general anesthesia with an associatom of $1 \mathrm{ml}$ of ketamine chlorhydrate $(50 \mathrm{mg})$ and $1 \mathrm{ml}$ of xylasine $(20 \mathrm{mg}$ ) administred by intraperitoneal injection.

All animals underwent a midline laparotomy and superior mesenteric artery occlusion utilizing a vessel loop. Leaving the artery occluded, the abdominal wall was closed.

After 60 minutes, the previous incision of the 32 animals was reopened in order to perform the intestinal reperfusion, releasing the vessel loop that occluded the mesentery artery. The reperfusion was confirmed by the reappearance of pulsation in the mesentery arcade and the change in color of the loops of the small bowel.

Before closing the abdominal wall, $2 \mathrm{ml}$ of isotonic saline solution were instilled in the peritoneal cavity of the animals of the control group and the same amount of $1 \%$ methylene blue was instilled in peritoneal cavity of the rats of the experimental group.

Four hours after the intestinal reperfusion, the animals of both groups were sacrificed for removal of the lungs, kidneys and small bowel. . The lungs were excised 
from all 32 rats. Simultaneously, the small intestine and kidneys were ressected from 10 animals of the control group and 10 animals of the experimental group.

The organs were divided into 3 parts: 1 segment was fixed in $10 \%$ formalin and sent for histological studies, and the remaining segments were stored in recipients with ice blocks for biochemical tests and for evaluation of tissue edema.

Xanthine oxidase enzyme activity was evaluated by quantification of uric acid from xanthine in $292 \mathrm{~nm}^{20}$. One unit of activity was defined as $1 \mu \mathrm{mol}$ of uric acid formed per minute at $37^{\circ} \mathrm{C}, \mathrm{ph} 7.5$, and expressed in $\mathrm{mU} / \mathrm{g}$ of tissue wet weight.

Tissue edema was evaluated using the wet / dry weight ratio. The samples were dried at a temperature of $80^{\circ} \mathrm{C}$ for 24 hours allowing for dry weight measurement ${ }^{21}$.

Samples from intestines, kidney and lungs were fixed in $10 \%$ formaldehyde, embedded in paraffin and sectioned. For the histological analysis of the ischemic intestinal lesion, the slides were stained with hematoxylin and eosin (HE) . The Park/Chiu scale (Chart 1) was used to grade the severity of the intestinal lesion in the animals of both groups. The Alcian Blue stain was used to quantify the goblet cells in a mean number of 12 high power fields per animal.

CHART 1 - Park/Chiu Histological Classification

\begin{tabular}{ll}
\hline & Park/Chiu \\
\cline { 2 - 2 } Chiu & normal mucosa \\
1 & Sub epithelial space at villous tips \\
2 & Extension of sub epithelial space with moderate lifting \\
3 & Massive lifting down sides of villi, some denuded tips \\
4 & Denuded villi, dilated capillaries \\
5 & Disintegration of lamina propria \\
Park & \\
6 & Crypt layer injury \\
7 & Transmucosa infarction \\
8 & Transmural Infarct \\
\hline
\end{tabular}

The histological analysis of the ischemic renal lesion was based on the vacuolization and detachment of the epithelial tubular cells from the superficial cortical, inferior cortical and medullar layers. These features can be observed in the early stages of renal ischemia. The severity of renal injury was assessed by the number of vacuolated and detached cells in 20 high power fields per animal. (Chart 2).
CHART 2 - Criteria for graduation of ischemia-reperfusion renal lesion

\begin{tabular}{lr}
$0-50$ vacuoles & $\begin{array}{r}\text { Slight vacuolization } \\
50-100 \text { vacuoles }\end{array}$ \\
More than 100 vacuoles & Intense vacuolization \\
\hline
\end{tabular}

Regarding the pulmonary lesion, the parameters analyzed were the degree interstitial edema and neutrophilic infiltration. The edema was graduated into: discrete $(+)$ if only focal alterations were present; moderate $(++)$ if multifocal alterations were present; and intense $(+++)$ if diffuse alterations were present (Chart 3). Neutrophilic infiltration was evaluated by the number of polymorphonuclear cells (PMN) in the alveolar septal wall. It was expressed as the mean number of PMN present per 10 high power fields.

CHART 3 - Criteria for graduation of interstitial pulmonary edema

$\begin{array}{lr}\text { Discrete }(+) & \text { Only focal alteration } \\ \text { Moderate }(++) & \text { Multi-focal alterations } \\ \text { Intense }(+++) & \text { Diffuse alterations }\end{array}$

To analyze the results, the Student-t test, nonparametric Mann Whitney test, and the Fisher exact tests were utilized.

$\mathrm{P}$-value was set at $\mathrm{p}<0.05$ indicating rejection of the null hypothesis.

\section{Results}

No deaths occurred during the course of the experiments.

\section{Biochemical study}

Regarding the evaluation of xanthine oxidase activity by indirect assessment of uric acid concentration, we verified that enzyme activity was present and its activity was similar in both studied groups. There was no evidence that the groups were different regarding to uric acid levels in any of the tissues analyzed. The values are presented on Table 1 , as well as the statistical significance.

TABLE 1 - Xanthine oxidase enzyme activity from intestinal, renal, and pulmonary tissue uric acid concentration

\begin{tabular}{|c|c|c|c|c|c|c|}
\hline & Group & Variable & $\mathrm{N}$ & Mean & Standard Deviation & $\mathrm{p}$-value \\
\hline \multirow[t]{2}{*}{ Intestinal } & Control & \multirow{6}{*}{ UricAcid } & 7 & 4.87 & 0.57 & $0.9015^{*}$ \\
\hline & Experim & & 7 & 4.91 & 0.45 & \\
\hline \multirow[t]{2}{*}{ Renal } & Control & & 10 & 4.46 & 0.54 & $0.9118 *$ \\
\hline & Experim & & 10 & 4.52 & 0.44 & \\
\hline \multirow[t]{2}{*}{ Pulmonary } & Control & & 16 & 2.32 & 0.18 & $0.7966^{* *}$ \\
\hline & Experim & & 16 & 2.31 & 0.17 & \\
\hline
\end{tabular}

(*) Mann-Whitney non-parametric test

(**) Student $\mathrm{t}$ - test 


\section{Tissue Edema}

Analyzing the wet/dry weight ratio (Table 2), we group than in the experimental group $(\mathrm{p}<0.05)$, in all tissues studied. . observed that it was significantly greater in the control

TABLE 2 - Intestinal, renal and pulmonary wet/dry weight ratio

\begin{tabular}{|c|c|c|c|c|c|c|}
\hline & Group & Variable & $\mathrm{N}$ & Mean & Standard deviation & $\mathrm{p}$-value \\
\hline \multirow[t]{2}{*}{ Intestinal } & $\overline{\text { Control }}$ & \multirow{6}{*}{$\begin{array}{r}\text { Wet/dry } \\
\text { weight }\end{array}$} & 10 & 4.49 & 0.17 & $<0.0001^{*}$ \\
\hline & Experim & & 10 & 3.58 & 0.15 & \\
\hline \multirow[t]{2}{*}{ Renal } & Control & & 7 & 4.99 & 0.18 & $0.0006^{*}$ \\
\hline & Experim & & 7 & 4.01 & 0.13 & \\
\hline \multirow[t]{2}{*}{ Pulmon. } & Control & & 16 & 6.15 & 0.21 & $<0.0001 * *$ \\
\hline & Experim & & 16 & 4.91 & 0.41 & \\
\hline
\end{tabular}

(*) Mann-Whitney non-parametric test

(**) Student t-test

\section{Histopathology study}

Small Bowel

We evaluated two histological parameters of the ischemic bowel: tissue lesion, based on the Park/Chiu grade system and on the number of goblet cells. The results are shown in the tables below (Tables 3 and 4).

When comparing the intestinal injury caused by ischemia and reperfusion in animals or the control and experimental groups, there was no statistical significance.

Table 3 - Result of tissue lesion analysis based on the Park/Chiu scale

\begin{tabular}{lll|l}
\hline Classification & Control Group & Experimental Group & p-Value* \\
\hline 0,1 or 2 & $5(55 . \%)$ & $2(22.2 \%)$ & \multirow{2}{*}{0.3348} \\
\hline 3,4 or 5 & $4(44.4 \%)$ & $7(77.8 \%)$ & \\
\hline Total & 9 & 9 & \\
\hline
\end{tabular}

(*)Mann-Whitney non parametric test

Table 4 - Comparison of caliciform cell count

\begin{tabular}{|c|c|c|c|c|c|}
\hline & Variable & $\mathrm{n}$ & Mean & Standard Deviation & p-value* \\
\hline \multirow{3}{*}{$\begin{array}{l}\text { Control } \\
\text { Experim }\end{array}$} & \multirow{3}{*}{$\begin{array}{l}\text { Number of } \\
\text { caliciform } \\
\text { cells }\end{array}$} & 8 & 37.65 & $1 ., 59$ & \multirow{3}{*}{0.1049} \\
\hline & & 8 & 45.07 & 11.37 & \\
\hline & & & & & \\
\hline
\end{tabular}

(*)Mann-Whitney non-parametric test

\section{Kidneys}

The quantitative analysis of the epithelial tubular cells, regarding vacuolization and detachment from the tubules, did not show any statistical significant difference between the control and the experimental groups, The results are shown on Table 5 and 6. 
Table 5 - Renal cellular detachment analysis

\begin{tabular}{llllll}
\hline Group & Variable & $\mathrm{n}$ & Mean & Standard deviation & p-value* \\
\hline Control & Detached cells & 10 & 10.52 & 2.93 & 0.6305 \\
Experim & superficial layer & 10 & 9.94 & 2.74 & \\
\hline \multirow{2}{*}{ Control } & Detached cells & 10 & 7.42 & 2.73 & 0.2799 \\
Experim & inferior layer & 10 & 7.88 & 2.00 & \\
\hline \multirow{2}{*}{ Control } & Detached cell & 10 & 1.52 & 1.26 & 0.9118 \\
Experim & medullar layer & 10 & 1.34 & 0.77 & \\
& & & & & \\
\hline
\end{tabular}

(*)Mann-Whitney non-parametric test

Table 6 - Renal vacuolization, percentage of occurrence.

\begin{tabular}{lcc}
\hline Vacuolization superficial & Control Group & Experimental group \\
\hline Absence or slight & $0(0 \%)$ & $0(0 \%)$ \\
Moderate or intense & $10(100 \%)$ & $10(100 \%)$ \\
\hline Total & 10 & 10 \\
\hline Vacuolization inferior & $5(50 \%)$ & $5(50 \%)$ \\
Absence or slight & $5(50 \%)$ & $5(50 \%)$ \\
Moderate or intense & 10 & 10 \\
\hline Total & & $10(100 \%)$ \\
\hline Medullar & $10(100 \%)$ & $0(0 \%)$ \\
Absence or slight & $0(0 \%)$ & 10 \\
Moderate or intense & 10 & \\
\hline Total & & \\
\hline
\end{tabular}

\section{Lungs}

Evaluating the interstitial edema and neutrophilic infiltration, a less important inflammatory process was seen in the experimental group, that is, in the animals treated with methylene blue (Figures 1 and 2). Fisher statistical test

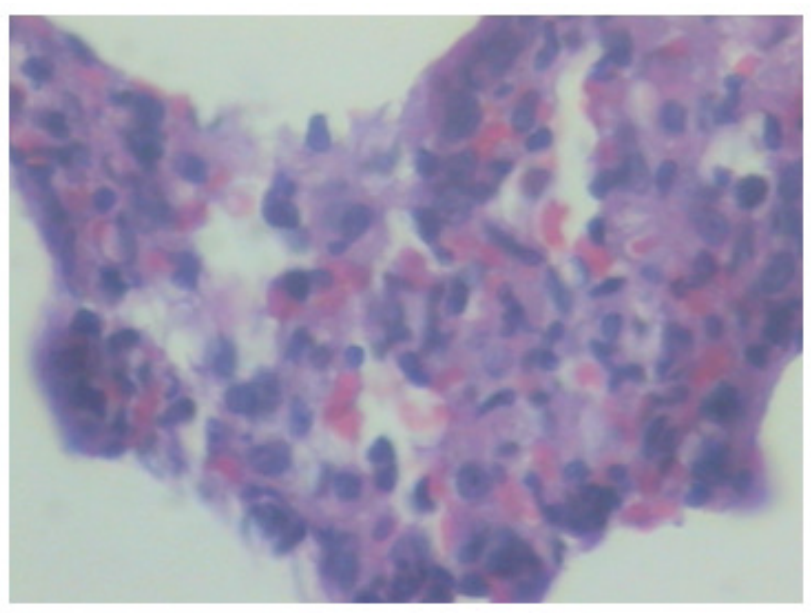

Figure 1 - Photomicrography of histological lung tissue from a control group animal, showing accentuated edema and an important leukocytic reaction $(\mathrm{HE}-400 \mathrm{X})$ demonstrate that the interstitial pulmonary edema was significantly greater in the control group $(p=0.0032)$ (Table 7). The mean number of polymorphonuclear leucocytes in the alveolar septal wall was 10.50 in the experimental group and 28.75 in the control group. This result is statistically significant $(\mathrm{p}<0.0001)$ (Table 8$)$.

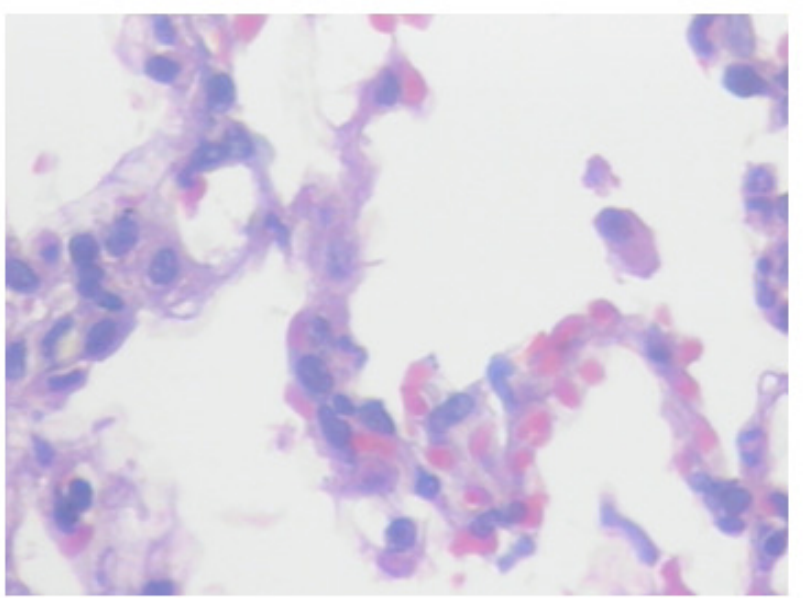

Figure 2 - Photomicrography of lung tissue of an animal in the experimental group after methylene blue treatment $(\mathrm{HE}-400 \mathrm{X})$ 
Table 7 - Evaluation of pulmonary edema in the control and experimental groups.

\begin{tabular}{lll}
\hline Interstitial edema $*$ & Experimental group & Control group \\
\hline Degree 1 - Slight & $11(68.75 \%)$ & $2(12.50 \%)$ \\
Degree 2 - Moderate & $5(31.25 \%)$ & $12(75.00 \%)$ \\
Degree 3 - Intense & $0(0.00 \%)$ & $2(12.50 \%)$ \\
Total & 16 & 16 \\
\hline
\end{tabular}

(*) Moderate and intense were grouped for test application.

Table 8 - Mean values and Standard deviations for neutrophil numbers, wet/dry weight ratios and xanthine oxidase enzyme activity by tissue uric acid concentration.

\begin{tabular}{l|lll}
\hline & Experiment Group n=16 & Control Group n=16 & P-Value \\
\hline Mean $\pm \boldsymbol{S D}$ & Mean $\pm \boldsymbol{S D}$ & \\
$\begin{array}{l}\text { Number of neutrophils } \\
\text { wet/dry weight ratio }\end{array}$ & $10.50 \pm 2.66$ & $28.75 \pm 3.89$ & $<0.0001^{*}$ \\
\hline $4.91 \pm 0.41$ & $6.15 \pm 0.21$ & $<0.0001^{* *}$ \\
\hline
\end{tabular}

(*) Mann-Whitney non-parameteric test

(**) Student t-test

\section{Discussion}

It is well know that prolonged ischemia in highly aerobic tissue produces necrotic cell death. It is now clear that short periods of arterial blood flow suppression, not long enough to induce necrosis, followed by reoxygenation can induce apoptotic cell death. The production of oxygen free radicals during reperfusion from ischemic tissue or from inflammatory cells that invade the tissue is well documented.

Much attention has been given to xantine oxidase enzyme as a contributor of ischemia/reperfusion induced remote organ injury. During ischemia, net catabolism of ATP increases the concentration of hypoxantine, the substrate for production of xanthine by xanthine oxidase., a process that requires molecular oxygen supplied by reperfusion.

Superoxide radical are then release, causing epithelial cell damage by peroxidation of cell membranes, as well as a probable activation of neutrophils. Regarding the microvasculature, the endothelial cell response becomes exacerbated, with the increase of reactive oxygen metabolites and decrease of nitric oxide.

The superoxide radicals are only moderately reactive and injurious to cells constituents, however when they are converted to peroxide or to peroxynitrites they become highly toxic. Many mediators have been implicated in the reperfusion phase, such as complement factors, proinflammatory cytokines, phospholipase A2 and PDGF ${ }^{26,}$ $29,30,31$.

Several experimental studies have reported attenuation of ischemia-reperfusion lesion, using different drugs such as pirfenidone, Ringer's ethyl pyruvate solution, alupurinol, quercetin and statins ${ }^{11,16,30,31,32}$.

In 1991, Salaris et al studied the utilization of methylene blue as an inhibitor of oxygen radical generation by xanthine oxydase enzyme activity. They demonstrated that the pairs of electrons of each enzymatic oxidation are transferred to the iron-sulfuric center of methylene blue, thus scavenging the free oxygen radicals and consequently protecting tissues from free oxygen radicals. Furthermore, they suggest that methylene blue represents a new class of anti-oxidant drugs.

The present study shows that reperfusion after 1 hour of intestinal ischemia induced bowel, kidney and lung injury. We quantified the xanthine oxidase enzyme activity indirectly by uric acid formation. It was demonstrated a significant increase in the release of xanthine oxidase in the intestine, kidneys, and lungs in both groups. The values obtained by spectrophotometry showed important biological enzyme activity in all animals of both groups. This corroborates with the theory that in both groups the activity of the xanthine oxidase was maintained, even with the use of methylene blue and under the same ischemic stress.

The significant increase in the wet-weight to dryweight ratio reflected the inflammatory process caused by the free oxygen radicals in all the studied organs, from experimental and from control group.

Although methylene blue functions as an acceptor of electrons from the enzyme reaction, it did not attenuate the morphological damages caused by ischemia and reperfusion in intestines and renal tissues. The intestinal mucosa is probably one of the most sensitive tissues to ischemia/reperfusion. Two distinct modes of cell death, apoptosis and necrosis are involved in the destruction of rat small bowel epithelial cells during I/R but the former found to be the major mode ${ }^{33}$. Despite that any histological grading system is supported in the literature, we chose the Park /Chiu grading system, since it seems suitable for assessing the evolution of injury from mild to severe and easy to use to ensure low inter observer-variability. The 
intestinal lesions graded according to Park/Chiu classification varied from subepithelial space at villus tips to disintegration of lamina propria and in both groups were similar. In any case transmucosal infarction or transmural infarction was observed. The goblets cells count was similar, since the mucous cell are damaged early in the ischemia and reperfusion.

According to Lai, the magnitude of renal dysfunction and its reversibility depend on the type and the duration of ischemia. He suggests a minimum ischemic period of 120 minutes for alterations in renal tubular function, followed by 60 minutes of reperfusion, which justifies the results found in the current study ${ }^{15}$. Other researchers found significant lesions with small periods of ischemia, however in models with different mechanisms of ischemia-reperfusion lesions, such as clamping of renal arteries.

In the our study, the degree of vacuolization presented in the renal epithelium cells as well as the number of cells detached from the tubules were the parameters used to evaluate the renal injury, since these features are observed in the early phases of ischemia and reperfusion. We did not find any statistical difference between the control and the experimental group.

Regarding pulmonary it was observed an attenuation of the pulmonary lesion, characterized by lower rate of neutrophil capture and lesser formation of interstitial edema when compared to the control group..

It seems that not only the oxygen radicals are involved in the ischemia and reperfusion tissular lesion , but other important factors like inflammatory response, mediated by cytokines and vascular response mediated by proteases and adhesion molecules must play also an important role.

Finally, we can suggest that in rats, the pulmonary lesion precedes the kidneys and intestinal lesion in the animals submitted to a period of 60 minutes of intestinal ischemia followed by 4 hours reperfusion. Similarly we observed that methylene blue was capable of attenuate the severity of the pulmonary lesions.

\section{Conclusion}

Methylene blue attenuate the pulmonary injury caused by ischemia followed by reperfusion. The same protective effect was not observed in small bowel and kidneys.

\section{References}

1. Greca FH, Biondo-Simões MLP, Ioshii SO, et al. Efeitos da isquemia e reperfusão intestinal na cicatrização de anastomoses do intestino delgadoestudo experimental em ratos. Acta Cir Bras. 2001; 16:9-15.

2. Edward MS, Cherr GS, Craven TE, Olsen AW, Plonk GW, Geary RL, Ligush JL, Hamsen KJ. Acute occlusive mesenteric ischemia: surgical management and outcomes. Ann Vasc Surg. 2003;17(1):72-9.
3. Lock G. Acute mesenteric ischemia: classification, evaluation and therapy. Acta Gastroenterol Belg. 2002;65(4):220-5.

4. Haimovic H. Metabolic complications of acute arterial occlusions. J Cardiovasc Surg. 1979;20(4):349-57.

5. Nilsson UA, Schoenberg MH, Aneman A, et al. Free radicals and pathogenesis during ischemia and reperfusion of the cat small intestine. Gastroenterol. 1994; 106: 629-36.

6. McCord JM. Oxigen-derived free radicals in postischemic injury. N Engl J Med. 1985; 312: 15963.

7. Hirata Y, Taguchi T, Nakao M, et al. The relationship between the adenine nucleotide metabolism and the conversion of the xantine oxidase enzyme system in ischemia-reperfusion of the rat small intestine. J Pediatr Surg. 1996; 31: 1199 203.

8. Pitt RM, Mckelvey G, Saenger FS, et al. A tungstensupplemented diet delivered by transplacental and breast-feeding routes lowers intestinal xantine oxidase activity and affords cytoprotection in ischemia-reperfusion injury to the small intestine. J Pediatr Surg. 1991; 26: 930-5.

9. Mc Quaid KE, Keenan AK. Endothelial barrier dysfunction and oxidative stress: role for nitric oxide? Exp Physiol. 1997;82(2):369-76.

10. Cohen SM, Siddigi FA, Darakchiev B, Fantini GA, Hairi RJ, Barie PS. Attenuation of acute lung injury caused by hind-limb ischemia-reperfusion injury by butylactone anti-inflammatory agent FL 1003. J Trauma. 1997;43(2):247-52.

11. Ciz M, Cizova H, Lojek A, et al. Ischemia/ reperfusion injury of rat small intestine: the efect of allopurinol dosage. Transplant Proc. 2001; 33: 2871-3.

12. Farmer DG, Amersi F, Shen XD, et al. Improved survival through the reduction of ischemiareperfusion injury after rat intestinal transplantation using selective $\mathrm{p}$-selectin blockade with p-selectin glycoprotein ligant-ig. Transplant Proc. 2002, 34: 985.

13. Galili Y, Bem-Abrahan R, Weinbroum A, et al. Methylene blue prevents pulmonary injury after intestinal ischemia-reperfusion. J Trauma. 1998; 45: 222-6.

14. Sileri P, Morini S, Schena S, et al. Intestinal ischemia-reperfusion injury produces chronic abnormalities of absortive function. Transplant Proc. 2002; 34: 984.

15. Lai IR, Ma MC, Chen CF, Chang KJ. The effect of an intestinal ischemia-reperfusion injury on renal nerve activity among rats. Shock. 2003; 19(5):4805.

16. Kahraman A, Erkasap N, Serteser M, Köken T. Protective effect of quercetin on renal ischemia/ reperfusion injury in rats. J Nephrol. 2003; 16(2):219-24. 
17. Ishii Y, Yamasawa H, Kitamura S. Role of oxidants in adhesion molecule expression and cytokine production. Nihon Kobu Shikkan Gakkai Zasshi. 1996; 34:126-30.

18. Salaris SC, Babbs CF, Voorhees III WD. Methylene blue as na inhibitor of superoxide generation by xantine oxidase. Biochem Pharmacol. 1991; 42: 499506.

19. Keany JF, Puyana JC, Francis S, et al. Methylene blue reverses endotoxin-induced hypotension. Circ Res. 1994, 74: 1121-5.

20. Hashimoto S. A new spectrophotometric assay method of xanthine oxidase in crude tissue homogenate. Analytical Biochemistry. 1974;62:426-35.

21. Stephens KE, Ishizaka A, Lamick JW, Raffin TA. Tumor necrosis factor causes increased pulmonary permeability and edema. Am Rev Respir Dis. 1988; 137(6):1364-70.

22. Atici A, Kaya Y, Coskun T, Aral E, Var A. Intestinal ischemia-reperfusion impairs liver regeneration after partial hepatectomy in rats. Hepagastroenterol. 2003;50(51):661-5.

23. Beckman JS, Parks DA, Pearson JD, Marshall PA, Freeman BA. A sensitive fluorometric assay for measuring xanthine dehydrogenase and oxidase in tissues. Free Radic Biol Med. 1989; 6(6):607-15.

24. Gobé G, Willgoss D, Hogg N, Schoch E, Endre Z. Cell survival or death in renal tubular epithelium after ischemia-reperfusion injury. Kidney Int. 1999; 56(4):1299-304.

25. Lien YH, Lai LW, Silva AL. Pathogenesis of renal ischemia/reperfusion injury: lessons from knockout mice. Life Sci. 2003; 74(5):543-52.

26. Benítez-Bribiesca L, Gómez-Camarillo M, Castellanos-Juárez E, Mravko E, Sánchez-Juárez P. Morphologic, biochemical and molecular mitochondrial changes during reperfusion phase following brief renal ischemia. Ann N Y Acad Sci. 2000; 926:165-79.
27. Hourmant M. Le syndrome d'ischémie reperfusion rénale. [Renal ischemia reperfusion syndrome. Nephrol. 1999; 20(7):371-5.

28. Galli Y, Kluger Y, Mianski Z, Iaiana A, Wollman Y, Marmur S, Soffer D, Chernikosky T, Klausner JP. Methylene blue: a promising treatment modality in sepsis induced by bowel perforation. Eur Surg Res. 1997; 29:390-5.

29. Carden DL, Granger DN. Pathophysiology fo ischaemia-reperfusion injury. $J$ Pathol. 2000;190:255-66.

30. Arumugam TV, Shiels IA, Margolin SB, Taylor SM. Brown L. Pirfenidone attenuates ischaemiareperfusion injury in the rat small intestine. Clin Exp Pharmacol Physiol. 2002; 29:996-1000.

31. Sims CA, Wattanasirichaigoon S, Menconi MJ, Ajami AM, Fink MP. Ringer's ethyl pyruvate solution ameliorates ischemia/reperfusion induced intestinal mucosal injury in rats. Crit Care Med. 2001;29:1513-8.

32. Yokoka N, O’Donnel M, Daniels F, Burne-Taney M, Keane W, Kasiske B, Rabb H. Protective fffect of HMG-CoA reductase inibitor on experimental renal ischemia-reperfusion injury. Am J Nephrol. 2003; 23:13-7.

33. Genescà M, Sola A, Miquel R, Pi F, Xaus C, Affaro $\mathrm{V}$, Hotter G. Role of changes in tissular nucleotides on the development of apoptosis during ischemia/ reperfusion in rat small bowel. Am J Pathol. 2002; 161:1839-47.

\section{Correspondence:}

Fernando Hintz Greca

Av. Visconde de Guarapuava, 5087/1401

80240-010 Curitiba-PR

fernando.greca@bbs2.sul.com.br
Conflict of interest: none

Financial source: none

Received: September 18, 2007

Review: November 20, 2007

Accepted: December 21, 2007

\section{How to cite this article}

Greca FH, Gonçalves NMFM, Souza Filho ZA, Noronha L, Silva RFKC, Rubin MR. The protective effect of methylene blue in lungs, small bowel and kidney after intestinal ischemia and reperfusion. Acta Cir Bras. [serial on the Internet]2008 March-Apr;23(2). Available from URL: http://www.scielo.br/acb 